\title{
Diaspora and Cultural Hybridity: A Postcolonial Reading of Jhumpa Lahiri's The Lowland (2013)(*)
}

\author{
Amany Abdullah AbdelAziz Eldiasty \\ Lecturer of English Literature \\ Faculty of Arts, Damietta University
}

\begin{abstract}
Within the theoretical framework of postcolonialism, this paper highlights the historical crisis that gives birth to new Indian identities in a process of cultural clash, acculturation, conflict resolution and Indian American hybridization. The main argument is that Indian diaspora exists in America and that cultural hybridity constitutes the pivotal theme in Lahiri's recent novel, The Lowland. The paper seeks an answer to the question: For how long will it take Indian generations to overcome the cultural clash and diaspora in the host culture and to adapt to the New Land Lahiri, as a second generation immigrant of Bengali origin, has some diasporic experiences to share with the world. She presents an objective picture of typical Bengali characters to emphasize some points. It takes so long a time for first generation immigrants to shed their differences and assimilate with the members of the host society. Only through friendship, love, and newly-found hybrid identity can generations assimilate and acculturate with the host culture. Second generation shows an extreme assimilation with the host society. Yet, there is a conflict between first generation and second generation concerning their ways of life. It is through the grandchildren or third generation of immigrant parents that reconciliation is achieved.
\end{abstract}

Key Words: Cultural dislocation, Culture Clash, Nostalgia, Diaspora, Search for Identity Acculturation, Hybridity, Assimilation.

${ }^{(*)}$ Bulletin of the Faculty of Arts Volume 80 Issue 2 Junary 2020 
الشتات والتهجين الثقافي في رواية الأرض المنخفضة للكاتبة جومبا

\section{لاهيزي}

د. أماني عبدالله الايسطي

\section{كلية الآداب جامعة دمياط}

من خلال الإطار النظري لنظرية ما بعد الاستعمار تلقي هذه الورقة البحثية

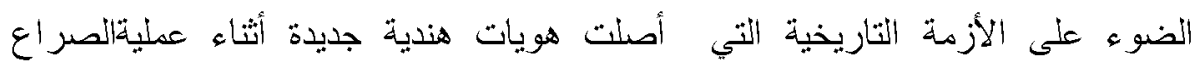

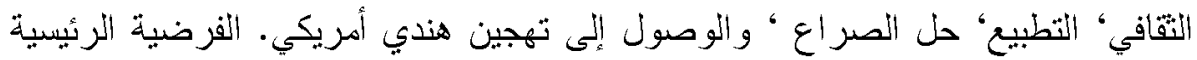
في البحث هي أن التثات الهندي داخل أُمريكا ثم التهجين التقافي يشكلان المحور الرئيسي لرواية لاهيري الحديثة الأرض المنخفضة. يجيب البحث عن التساؤل: كم

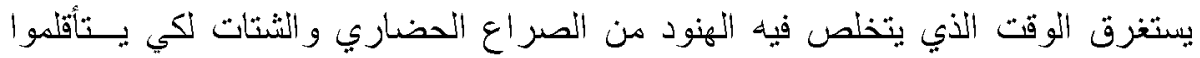
ويندمجوا في التقافة المضيفة.

الزوائية جومبا لاهيري كواحدة من مهاجر ات الجيل الثثاني والتي تحمل أصل

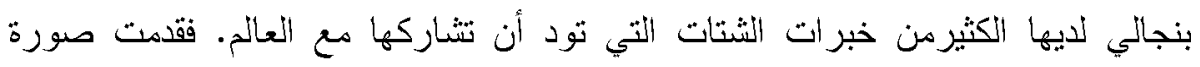

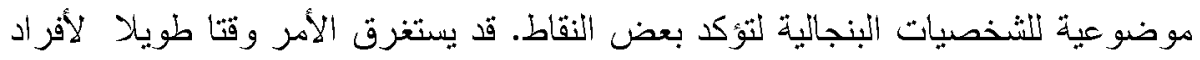

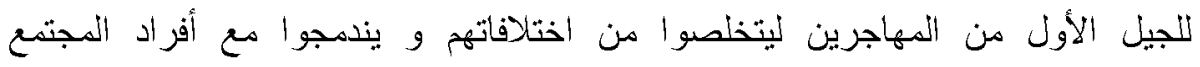

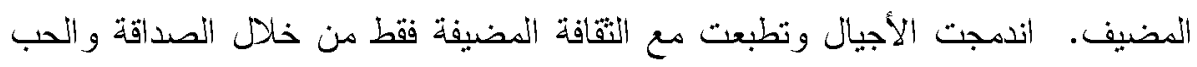

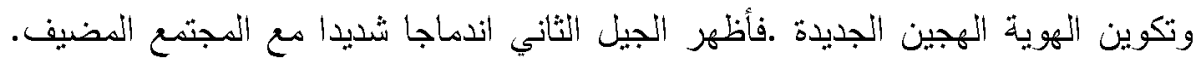

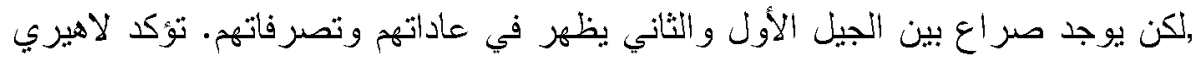
ان التصالح يمكن تحقيقه فقط من خلال الأحفاد او الجيل الثالث من المهاجرين الأباء.

\section{كلمات البحث}

الإقتلاع الحضداري، الصدام الثقافي، الحنين إلى الوطن، الثتات، البحث عن التهن الهوية، التطبيع، التهجين، الإندماج. 
This paper highlights the historical crisis that gives birth to new Indian identities in a process of immigration, cultural clash, acculturation, conflict resolution, assimilation and Indian American hybridization. The main argument is that Indian immigrants are diasporic in America and that cultural hybridity constitutes the pivotal theme in Lahiri's recent novel, The Lowland. The paper seeks an answer to the question: For how long will it take Indian generations to overcome the cultural clash and diaspora in the host culture and to adapt to the New Land?

India, having a significant number of emigrants, has created an impact as far as Asian diasporic literature is concerned. Indian immigration and establishing Indian settlements abroad can generally be divided into two periods. The first is the movement of South Asian people to other British colonies and it lasted from 1830s to the independence of South Asian nations. The second is the movement of South Asians to Europe and the United States and it started in1947 till now. Before that date, India was a British colony. India ceased to be a colony and turned to be a Sovereignty State in August 1947. After the end of World War II, many Third World countries saw the light of independence. These peoples were absorbed in the newly found national identity. Yet, a few of these countries had to assume a new hybrid identity which is away from their homeland.

The United States, a country built upon immigration, has a long history of novels dealing with both emigrants and bicultural postemigrants. Traditionally these have dealt primarily with earlier waves of emigration - German and Scandinavian, then Irish and Jews, while in recent time the Indian and the Arab diasporas have taken on a new prominence. Through the process of globalization, there is an access to multiple cultures and multiple choices of identities. A significant global phenomenon, large scale emigration from South Asia, especially India, has established a series of diaspora communities worldwide. Though America has been a great attraction for the 
youngsters to achieve their dreams and aspirations, it has also been a "melting pot" where the immigrants lose their roots and origins.

Diaspora is a term that was originally used to refer to the dilemma of the Jews living outside Palestine and making Jewish ghettoes as accommodation. It suggests "a dislocation from the nationstate or geographical location of origin and a relocation in one or more nation-states, territories, or countries" (Peters,2013,p.23). As location and dislocation along with travel have been human activities across the races of the globe, the term has become an interesting area of study and has been broadly defined as

a nation of socially interdependent and geographically dispersed communities. A group, or nation, of people seeing themselves as constituting a community of origin, the diaspora is usually regarded as relying on shared beliefs and organizational or institutional frameworks that keep its people together. (Pétriat,2017,p.187).

Diaspora can refer to the movement of the population from its original homeland. It has created numerous Indian communities around the world, especially in the United States. The immigrants and their descendants are widely dispersed across the globe. The diversity of the religious life of South Asia is repeated in the diaspora. There are two types of diaspora: it is either a forced migration on accounts of slavery and labour or a voluntary migration for reasons of business, education and wealth after Indian Independence. Diaspora has recently become an analytical tool to explain diverse practices of community formation and global movement in the second half of the $20^{\text {th }}$ century. The Indian diaspora is the product of a colonial past. Thus, the Indian literature written in English emerging from the former colonies falls under the category of postcolonial literature, a fact which has required the adoption of the postcolonial approach in this paper. Since postcolonial studies expanded its scope to include the United States (not as an imperial power in the past or the present), post $1965^{(1)}$ immigrants become a privileged area of critical attention. 
Migration has become a vital issue and an area of study because of the constant move of large numbers of people to different locations. People move from one place to another because of some reasons such as bloody wars, political persecution, natural calamities or economic aspiration. It takes various patterns: while some people never move, others could go back and forth between countries and build up ties to more than one place. Their contingency does not delete their desire for belonging since they are strangers in a strange land. One finds some others residing outside their countries of origin for decades and becoming part of other vibrant communities; they make a lasting remark on their host countries. Relocating migrants to the New Land, America, means removing the protective shield of "the known" to them, thus feeling insecure in the new country. The first generation immigrants try to hold the grip of the past. They are torn between what they should traditionally do and what they shouldn't do. This sense of insecurity merged with alienation in the Newland finds vent in the writings of diaspora writers.

Many studies tackled diaspora, immigration and hybridity in literature but none as yet applied these terms on Jumba Lahiri's The Lowland though the novel was long listed for the booker prize in 2013, and in 2014 it won the DSC Prize for South Asian Literature. In 2015, Barak Obama conferred Lahiri the 2014 National Humanities Medal in the White House since she illuminated the Indian American experience in wonderful novels of estrangement and belonging. Yet, during my research process, I come across some theses which attempt to give an analysis to Lahiri's writings such as, Jhumpa Lahiri: The Master Storyteller published in 2002 by Suman Bala.

Born to Bengali parents who moved to London and then to America, Jhumpa Lahiri (1967- ) takes pride in her cultural heritage. Through her writings, she provides insights into the experiences of Indian immigrants as well as the process of their acculturation into American culture. She is considered the spokesperson for Bengali 
community in the USA through publishing novels of shared experiences. In his book Literary Text and the Immigrant Imaginary, Arnold H. Itwaru writes:

[T] he immigrant writer is not merely the author who speaks about the immigrant experience, but who has lived it $[\ldots]$ one who is familiar with some of the inner as well as the outer workings of these particular contexts. (Itwaru,1990,p.25).

Lahiri stresses that she is interested in writing stories that have a universal appeal. Such stories happen to be dealing with Indian or Bengali characters because of her unique bicultural upbringing. She refers to that influence of her upbringing clearly in an interview entitled "Finding America, Losing Home" with Michel Martin in New Channel NPR:

I suppose...my novels are being held as, sort of, you know, almost sociological studies of the Indian immigrant community, which in my opinion, they're absolutely not....I don't think that's my responsibility as a writer. My responsibility is to paint a real portrait, a true portrait.(Lahiri,2008,para.28)

Lahiri emphasizes that she presents an objective picture of the Bengali character immigrants living in the American society. She depicts a true image of the adventure of migration. She is interested in the idea of the experience of "Indian people being transplanted into a new soil" (Schillinger, 2008, para.3).The diasporic experience of the Indian migrants to the new land results in a cultural clash from which they suffer. These experiences comprise a sense of cultural dislocation, anxiety in the new land and nostalgia for their motherland.

Lahiri's outstanding contemporary novel The Lowland (2013) takes its inspiration from Naxalite Movement, an Indian upheaval in 1967. Being a second generation immigrant herself who loves her Bengali culture, Lahiri depicts typical Indian characters. The novel discusses the experiences of immigrants and their difficult adjustment 
to the American culture. Raised in Rhode Island, Lahiri moves the events of the novel from India to America across successive generations as she herself never feels fully Indian or fully American.

The novel chronicles two Bengali brothers-Subhah and Udayan-belonging to the Mitra family who, at first, seem quite identical and inseparable, yet turn out to be of two different attitudes, aspirations and ideologies. They grow up in the lowland of North Calcutta in the 1950s. They live closely connected with a traditional Indian family in Tollygunge:

Subhah was thirteen, older by fifteen month. But he had no sense of himself without Udayan. From his earliest memories, at every point, his brother was there. (Lahiri, 2013,p.6)

Their ideologies change when they come of age. While the elder brother decides to migrate to the United States, the younger refutes his brother's proposal of joining him in his pursuit, saying: "How can you walk away from what's happening? There's of all places" (p.30), referring to the turbulent events that have taken place in India.

Udayan, the younger of two brothers in Calcutta is attracted to Naxalite movement, a radical left movement that calls for equal distribution of property and income. Its name is derived from Naxalbari, a tiny village near the Indian city of Calcutta where poor serfs rise up against landlords and the police in 1960s. This movement echoes Mao's earlier revolution in China. Udayan is involved in murdering a policeman, something which brings him to his fatal destiny. Udayan is shot dead by the police in the lowland in front of his parents and his expectant wife.

On the other hand, his older brother, Subhash, an entirely different character, is passive and not interested in politics. He pursues a $\mathrm{PhD}$ in Oceanography in the USA. Yet, a dutiful son, he returns to his motherland from graduate school in the United States to console his parents and to commemorate his only brother's death. There, he finds himself confronted with Gauri, Udayan's pregnant widow. She 
is badly treated by his grieving parents because she and Udayan got married secretly without inviting the relatives from both sides. Her residence with them is not a pleasant experience but still she is at their home as their son's expectant widow. Subhash knows of his parents' plan to take the child from Gauri after birth. Feeling responsible, he proposes to her and brings her to Rhode Island in the USA. Gauri gives birth to a girl named Bela. Meanwhile, Gauri pursues a $\mathrm{PhD}$ of her own in philosophy. Though still grieving for her dead husband Udayan, she agrees to marry Subhah to join him in Rhode Island. The novel ends when Bela is almost in her fourth decade. Here we are faced with four successive generations of the Indian Mitra family: two generations belonging to their homeland and the other two generations residing in the host land.

In Edward Said's Reflections on Exile\& Other Essays, he describes two contradictory modes:

Nationalism is an assertion of belonging in and to a place, a people, a heritage. It affirms the home created by a community of language culture and customs, and by doing so, it fends off exile, fights to present its ravages. (Said, 2000, p.176)

The feeling of nationalism is a celebratory attempt to maintain identity, cultural norms and traditional values. This positive mode is set in sharp contrast to the mode of rejection, that of being in exile. Yet, nationalism necessitates resistance which requires cultural violence and physical violence. In The Lowland, Udayan, the younger brother in the Mitra family, tries to discover his roots and his national identity. He defines himself in his struggle with the Indian tropes to get home to India again. In a scene similar to the "Wine Shop" in Charles Dickens' A Tale of Two Cities, when one of the revolutionaries and poor residents of ST. Antoine dipped his finger in some mud made red with the dropped wine and wrote on the wall five big letters BLOOD - an indication that the French are soon going to break out a bloody revolution to get rid of injustice and despotism, 
Udayan, too, dipped his hand in the fresh real blood of the policeman, "writing the party's initials on the wall as the blood leaked down his wrist into the crook of his arm before he ran from the scene"(Lahiri,2013,p.404).Udayan's action is an indication that blood shedding is a means to gain political freedom and obtain national identity. Being a second generation, his connection with India has been stories heard from his parents about their ancestral land. Having heard about the Naxalite movement, he fervently joins the activists. He has been distanced and alienated emotionally in his attachment to the Naxilbari. He chooses to be an active part of that turbulent movement to ensure his national identity, proving what Edward Said describes: "Nationalism is an assertion of belonging" (Said, 2000,p.285).

Udayan's identity is formed by his association with his root culture, language and the history of his motherland. He chooses his own ways of living and marries Gauri, his friend's sister, against the will of his parents. He endangers his life by involving himself in the turbulent activities. Having much in common with Gauri, he decides to marry her secretly though the Indian tradition would assume that his parents would have chosen him a wife. Lahiri in The Lowland is against the brutalities exercised by the Naxalbaries in murdering the policeman because "[I]t was they who were innocent of the things he'd done"(p.404). Lahiri chooses the Naxalite Movement as the backdrop of her setting. She depicts 1970 's turbulent daily life happenings of the Naxalite movement, the students and the system of education being badly influenced by what took place at that time.

The diaspora is formed through conflicts between two different cultural backgrounds which constitute multiple identities. Immigrants cannot easily adopt the host culture. They cannot blend in with the other Americans. It is this slow assimilation of the first generation immigrants into America that Lahiri deals with great zeal and knowledge. She has largely focused on the problems and tribulations 
of life that her characters face during their adjustment in the new environment. They are unable to lose their cultural identity and hence feel nostalgic to their origins. To solve this culture clash, immigrants search for people who share a common identity (history, culture, heritage, language\& religion) with them and they form groups and communities in certain spaces where they meet and communicate. They establish diasporic communities, a process which differs from one place to another in the same society.

Feeling culturally dislocated, Subhah has to adapt to the socalled mainstream culture if he is to reside in America. An immigrant, Subhah has to shed his differences and melt with the other members of the American society. In fact, he hardly makes a reasonable adjustment to the social values of the New Land which are utterly different from those with which he is familiar back in his cultural heritage. He chooses to spatially isolate himself in a rural area, Rhodes Island.

Subhash's acculturation process goes very slowly. Upon his arrival to Rodes Island, he has to live in an apartment. He shares it with an amiable Quaker activist who is a member of the Christian group called The Religious Society of Friends. Their apartment is close to the University campus and separate from the Indian community. That man teaches Subhash many things about cars, American lifestyle, American driving, beer and food. From Lahiri' s perspective,

[T] he difference was so extreme that he could not accommodate the two places together in his mind. In this enormous new country, there seemed to be nowhere for the old to reside. There was nothing to link them; he was the sole link. (Lahiri, 2013,p.41)

Though Subhash voluntarily travels to and is welcome in the New Land, he does experience pangs and anxiety of cultural dislocation from his homeland as one of the first generation immigrants. Once tension occurs between two different cultures, there appears a "third 
space" which according to Homi Bhabha, "raises questions of identity and the original culture." In an interview with J. Rutherford, Bhabah indicates the importance of hybridity:

[It] is not to be able to trace two original movements from which third emerges, rather hybridity according to me is the Third Space, which enables other positions to emerge. (Bhabah,1990,p.211)

Bhabha's "Third Space" denotes the possibility of producing a new identity that rejects all fixed values and rigid thinking, and embrace new ways of thinking. Through hybridity and the construction of an "in-betweenness" culture (Bhabha,1999,p.4), the long distance separating the homeland from the host land is tightened. A postimmigrant, Subhash suffers diasporic experiences while pursuing his dreams in the host culture.

The first generation immigrants can still return to India sometimes either to get married to an Indian girl of their parents' choice or to visit their relatives on occasions of paying condolences and the like. They can still have contacts with their native land. They still carry their valid Indian passports. Subhash notices that his Quaker fellow is married to an American wife. They have two hybrid children who "looked like neither of their parents"(p.44). Subhash wonders whether his Indian colleague's family reacts to their son getting married against their will, choice and the family's Indian tradition. Subhash's inner thoughts reveal his connection with his root culture. On the other hand, second generation immigrants struggle because they do not know where they originally come from. They stand in a certain place between the country of their birth (America) and the country of their origin (India). They created a "third space" to live in.

Strictly speaking, The Lowland is a post-emigrant novel, showing a bitter conflict between the apparently assimilated children of Indian emigrants and their parents. Lahiri offers a wide range of implicit models of how identity is formed since the search for identity constitutes an important leitmotif in American Indian writings. 
Identity, which is a "production, which is never complete, always in process, and always constituted within, not outside, representation" (Hall,1990, p.222), is sometimes based on personal qualities that are revealed during the tribulations of life. Yet, it is somehow reconstructed in Lahiri's The Lowland as a way of adapting to the new host society.

Lahiri deals with Bengali intellectuals who have immigrated from their motherland for one reason or another. For instance, Subhash, being wise, goes to the United States to pursue his academic endavours, and to achieve prosperity and economic welfare. He, the eldest son, cannot break away from the Indian traditions of the family. His commitment to the Mitra family means diasporic ties to his motherland and an interest in the Indian culture. At first, he was ill at ease at the Rhode Island, but then he eventually learns to live away from his family members. He maintains a safe distance through leading a diasporic life in America. Subhash's diasporic ties denote cultural and social commitment to his homeland over that of the host land. Feeling nostalgic, he does not break his ties with his ancestral homeland. Though living abroad, Subhash keeps in touch with his younger brother. He spends several decades in America and he should have been enticed to make a compromise with his Indian traditions and values. Yet, in order to prosper he has to move with the requirements of the New Land.

In a way to adapt, Subhash tries to find a similarity between the beaches of Rhode Island and the lowland surrounding his native land, Calcutta. According to him, "Both places were close to sea level, with estuaries where fresh and salt water combined"(p.42). He lives in the USA. After marrying Gauri, both feel isolated in this New Land. Such a feeling is intensified the moment both think of what they left behind in Calcutta. Only for one time after his 'marriage' does he return to Calcutta with Bela, Gauri's daughter, when his father died. Gauri refuses to accompany them to India as her travel will remind her 
of her awful past life back there. She claims that she has to finish her thesis in USA. Gauri fits in culturally and socially in the host land. She feels so comfortable within and she is fluent in American culture norms with an Indian accent.

Gauri's marriage to Subhash is a step to acquire strength and stability in social life and to dismantle the odds imposed on her while she married Udayan. She moves to Rhode Island in an attempt to escape as far as possible from her extended family and the culture she has been caught in. Living in a family of unwelcoming strangers who do not approve her marriage to their son, Udyan, is quite disturbing to her. She immerses herself into new life in Rhode Island. Lahiri depicts the isolation Gauri lives in and the loneliness she feels while living with Udayan's unwelcoming parents. Later on, Gauri undergoes a tense and turbulent process of identity formation which mirrors the confusion encountered regarding her husband's death during the Naxatile movement. Travelling to the States has been her refuge. The memories of her past life haunt her while she lives with her new husband, Subhash. Feeling fragmented, she leaves her young daughter with her uncle, now her step-father, seeking a degree and a career to build herself once again.

Hybridity is a major theme in postcolonial literature. It occupies a central place in post-immigrant literature. It can be a compromise between the colonial domination and its resistance, a mitigating factor between the homeland and the host land. In his book The Location of Culture (1994), Homi Bhabha defines the term as

[T] he sign of productivity of colonial power, its shifting forces and fixities; it is the name for the strategic reversal of the process of domination through disavowal... [It] is the revaluation of the assumption of colonial identity through the repetition of discriminatory identity effects. [Hybridity] displays the necessary deformation and displacement of all sites of discrimination and domination. (p.112) 
Hybridity affects both the colonized and the colonizer. For Bhabha, culture is not a static entity; it cannot be fixed in time and place. There is no pure, static Indianness nor is there an uncontaminated Americanness that can be studied or even turned to. Such a notion of pure culture, according to Bhahba, is a myth. All cultures are characterized by a sense of mixedness which Bhabha refers to as "hybridity". According to Paul Jay, cultural hybridity refers to "the necessity of cultural conversion [that] led to the creation of indigenous subjects" (Jay,1999,p.178). Through mutual interaction between the colonized and the colonizer in the host land, there exists a new hybrid generation. This cultural hybridity, according to A. Rutherford, is "celebrated and privileged as a kind of superior cultural intelligence owing to the advantage of in-betweenness, the straddling of two cultures and the consequent ability to negotiate the difference" (Rutherford,1990,p.158). In his discussion of hybridity, Bhabha introduces a significant concept which is "borders," and the concept implies important thresholds full of ambivalence since these borders are the endpoints where two places join and separate (Bhaba,1994,p.153). The new hybrid identity emerges from mixing the elements of the host land and those of the homeland. Lahiri has clearly managed to show those getting a new hybrid identity as straddling two cultures, yet assimilating to the host culture.

The search for identity is situated within the negating tropes of assimilation. At first, Gauri's nostalgia never allows her to fully integrate herself not only in an intimate relation- ship with Subhash but also in the cultural milieu of the USA. Though she is attracted to traditional practices and indigenous things, she displays no Indian native values. For her, India means marrying Udayan, an activist with an Indian national identity, whom she loves dearly almost all her life. A simple girl, she is not attracted to what most girls in her age are often infatuated by (p.56), an attribute that fascinates Udayan. 
A girl from North Calcutta, Gauri leaves behind her all the ancient manners, likes. Instead, she receives new ones from the New Land. She tries to adapt to the new weather in Rhodes Island through comparing it to the air heavy with humidity back in Calcutta:

She had grown up in such weather. But here, where just months ago it was cold enough for her to see her breath when she walked outside, it came as a shock, as something almost unnatural. (Lahiri,2013,p.169)

She wants to get rid of her haunting past, her natural beauty which Udayan used to admire. She strives to define herself through her study. Migration to the States allows her a spacious room for liberation. It also permits her to construct her memorable past. Her intellectual and academic pursuits are her only means of escape from that past. She prefers to study since her grandfather, a professor of Sanskrit, "died with a book on his chest, who'd inspired her to study what she did" (p.69). To solve the mystery of time and to heal her fragmented existence and divided identity, Gauri wants to study and teach philosophy. She wants to establish herself as an intellectual in the host culture. She struggles a lot to create her scholarly personal identity. She frequents conferences to maintain visibility and status. Her marriage with Subhash failed. Subhash's efforts to develop an intimate relationship with her failed, too. Gauri's study room is her bedroom too and there is no attachment between them as a husband and wife.

In a way to cope with the American life style, Gauri destroys her Indian clothes, the things she used to put on while in India living with Udayan and his traditional Bengali family. She has a new striking look:

She knew that there weren't too many women who looked like her on the campus. Most of the other Indian women wore saris. But in spite of her jeans and boots and belted cardigan, or perhaps because of them, Gauri knew she stood out. (Lahiri,2013,p. 204) 
Applying Gordon's words to Gauri as one of a minority group arriving on the scene, she strives to culturally assimilate with the New Land (1964,p.77). Yet, the cruel memories of Udyan's murder haunt her. She is still connected to the lowland, the place which witnessed her husband's merciless murder. It is this depressing image of the lowland that shapes her life in the United States with dark and gloomy shades of unhappiness, dissatisfaction and ambiguity. Ambivalent memories of the past haunt her in the host land.

[T] he love she'd once felt for Udayan refused to reconstitute itself. Instead there was a growing numbness that inhabited her, that impaired her(...). Anger at him for dying when he might have lived. For bringing her happiness, and then taking it away. For trusting her, only to betray her. For believing in sacrifice, only to be selfish in the end.(Lahiri,2013,p.195)

She gets weary of her past. She only finds solace in studying philosophy. Gauri goes after her dream, seeks a career in California college and ignores her daughter. She uses her customs, popular culture, and religion in innovative ways to assert herself in public space. She leaves behind her all the ancient manners and receives new ones from the new mode of life she embraces and the promising position she gets. She becomes an American by being received in international conferences. In this way, she is moving from the margins of the host culture to the center. She ends up being alone and regretting her mistakes. She never makes an attempt to communicate with her only daughter or her husband. Choosing to be away from Subhash and Bela, Gauri allows her second husband and daughter to acculturate to the demands of a diasporic and global world.

Feeling dejected after her husband's death and realizing that he has used her for achieving his political purposes (Lahiri,2013,p.349), she avenges him through keeping away from their daughter, Bela. Though she provides the anchor to which her only daughter is attached, she embarks on a transnational migration leaving her new 
unitary family members (her daughter and husband) behind. Years pass. In a global world, she tries to search for her daughter on internet sites to trace her news but in vain; she never found her profile. Due to the new technology, this new diaspora has easy access to the motherland.

[Gauri] cannot avoid it; she is a member of the virtual world, an aspect of her visible on the new sea that has come to dominate the earth's surface. There is a profile of her on the college website, a relatively photograph. A list of the courses she teaches, a trail marking her accomplishments. Degrees, publications, conferences, fellowships. Her e-mail, her mailing address at the department, should anyone want to send her something or get in touch. (Lahiri,2013,p.331)

Gauri, being diasporic, shapes technologies for her own creative and strategic purposes. Once, a candidate comes asking her permission to conduct an interview with her about the Naxalbri movement. She apologises because she senses that her name may be on the list of those involved in the Naxalbari uprising back there in Calcutta. She is truly involved in one way or another in the murder of the policemanthe father of the six-year-old-boy-through delivering notes and doing some tasks assigned to her by her then husband Udayan (p.349). After some negotiations with the candidate, she approves to help him, saying: "Listen, I can tell you what I know. But I don't want to be part of the book" (p.334). She gets to know many news about the founding members of the "movement that still threaten[s] the Indian state"(p.336). She types the names of some revolutionaries such as Kanu Sanyal who had "gone to China to meet with Mao, [had] spent close to a decade in jail, [and had] been the chairman of the communist Party of India, Marxist-Leninist. Following his release, he'd renounced violent revolution"(pp.336-337).Through technology, Gauri could see the seventy-year-old-man committing suicide. The image of that man haunts her memory for the following days. She is 
wondering how come a courageous man like Sanyal who refused to bow his head all his life long, ends his life in such a passive way.

On the other hand, the novel shows an apparent assimilation of children represented in Bela, "a rebel with a tattoo on her ankle". Unlike her mother, Gauri's daughter seems indifferent to her past and she develops a relationship with an American colleague. Bela as a second generation immigrant lives in the "melting pot" where social, psychological, political, geographical, and personal ideologies of the past and the present in the homeland and the host land affect one another. Bela acts in a way that pleases her with disregard to the Indian traditions. Though Lahiri presents the novel from various perspectives, the most important scenes are presented from Bela's perspective as a young hyphenated female narrator who is attempting to understand something which happened perhaps before her life time. When her mother abandoned her, she continues to live with her stepfather. Realising that the man who fathers her is not her real father, she undergoes a trauma, whereby a bad change takes place and she rejects Subhash. According to her teachers:

She no longer seemed connected to the other students.... In the cafeteria, at the lunch table, she sat alone. She hadn't signed up for any clubs. After school she had been seen walking by herself. (Lahiri,2013,p.258)

Her teachers suggest that Bela have to see a psychologist. She has many relationships with several men to eschew questions regarding her national belonging. Though she is the offspring of two loving Indian parents, she lives with two unloving ones. After a time, she overcomes the crisis. For college, she majors in environmental science. She leaves her step-father, and lives on her own. She discovers her new identity through

working as an environmental apprentice in the field, [p]utting in irrigation lines, weeding and harvesting, cleaning out animal pens [,p]acking crates to sell 
vegetables,[and] weighing them for customers on the side of the road. (p.265)

She gives birth to an illicit child, and goes for the single motherhood. She is quite acculturated and assimilated to the American core culture. Apparently, she does not feel alienated since she is born American and her only culture lies in the American society.

Gauri's actions are responsible for the downfall of almost four generations in one family. She travels to America while pregnant with Udayan's baby in search of happiness and true identity. Almost three decades passed, Gauri is getting old and weak. When Gauri happens to see her almost 40-year-old daughter, Bela rejects her, falsely telling her little Meghna that her grandmother is already dead. Bela's first encounter with her mother after 25 years of utter absence is cruelly insulting:

How dare you set foot in this house... Why have you come here....Get out. Go back to whatever it was that was more important ...I can't stand the sight of you...I can't bear listening to anything you have to say....I've known for years about Udayan....I know who I am...You're as dead to me as he is. The only difference is that you left me by choice (pp.374-375 Ellipsis is mine).

Bela's words are like bullets that silence her mother. Though Americanised, Bella seems to question the values of her Indian parents. She is deeply pained by her mother's actions. Finally, Gauri decides to go back to Calcutta to see her brother. Despite the turbulent events in India, "[t]he Indian passport she continued to carry, the citizenship she'd never renounced, enabled her, the following morning to board another plane" (p.378). Much to her bewilderment, she finds no trace of what happened to Udayan in the lowland in North Calcutta forty autumns ago. She realises the falsity of her whole life:

Scarcely two years of her life, begun as a wife, concluded as a widow, an expectant mother, an accomplice in a crime. It had seemed reasonable, what Udayan had asked of her. 
What he'd told her: that they wanted a policeman out of the way. Depending on one's interpretation, it had not even been a lie.(Lahiri,2013,p.383)

She secretly acknowledges her role in the crime during the Naxal movement. "She was the sole accuser, the sole guardian of her guilt. [She was] protected by Udayan, overlooked by the investigator, [and] taken away by Subhash" (p.383). According to her, she is "sentenced in the very act of being forgotten, punished by means of her release"(p.383). She ends up being furious at learning that her dead husband has implicated her in a crime.

It is through the newly born grandchildren that compromise and reconciliation between generations will be achieved in the host land. Meghna, Bela's daughter, wants to see Gauri again. In a letter sent to Gauri without salutation, Bela tells her: "Meghna asks about you. Maybe she senses something, I don't know. It's too soon to tell her the story now....If she wants to know you, and to have a relationship with you, I'm willing to facilitate that. This is about her, not about me. You've already taught me not to need you." (Lahiri,2013,p.389). Though second generation children of immigrant parents turn Americanized, and seemingly adopt the cultural norms of the host land, they never feel fully satisfied.

Lahiri depicts the life experiences of many generation immigrants in The Lowland, bringing out the problems of adaptation and adjustments in the host culture. The novel presents the experiences of three successive generations in the New Land. Lahiri, as a second generation immigration of Bengali origin, has some diasporic experiences to share with the world. She presents an objective picture of typical Bengali characters to emphasise some points. It takes so long a time for first generation immigrants to shed their differences and melt with the members of the host society. Though a return to the motherland is desirable, it is not a necessary part of their diaspora. Only through friendship, sympathy, love, 
success and electronic media can generations assimilate to and acculturate with the host culture. She, as a second generation, does not have the same anxiety felt by first generation immigrants to the host culture. Second generation shows an apparent assimilation with the host society. Bela, for instance, enjoys her life to the most as an American. Yet, there is a bitter conflict between first and second generation immigrants. It is through the third generation of immigrant parents that reconciliation is achieved as shown in Lahiri's The Lowland.

\section{Notes}

(1) 1965 Immigration Act explicitly banned all kinds of discriminatory practices in terms of race, sex, religion, nationality, birth place and residence in the USA. 


\section{References}

Benhabib, Seyle\& Judith Resnik. (Eds.). (2009). Migration and mobilities: Citizenship, borders, and gender. New York: New York University Press.

Bhabha, Homi. (1994). The location of culture. London\& New York: Routledge.

---.(Ed.). (1999). Nation and narration. London\& New York: Routledge.

Hall, Stuart. (1990)."Cultural identity and diaspora" in Jonathan Rutherford (Ed.),Identity: Community culture, difference (pp.222-237).London: Laurence\& Wishart.

Gordon, Milton. (1964). Assimilation in American life: The role of race, religion, and national origin. New York: Oxford University Press.

Itwaru, Arnold H. (1990). Literary text and the immigrant imaginary. Toronto: TSAR Publication.

Jay, Paul. (1999). "Hybridity, identity and cultural commerce in Claude Mckay's Banana Bottom." Callaloo, 22 (1), 176-194.

Lahiri, Jhumpa. (2008). "Finding America, losing home". Michel Martin. Interview, New Channel NPR. Retrieved from https://www.npr.org/ templates/story/ story.php? storyId = $\underline{89461076}$

Lahiri, Jhumpa. (2013). The lowland. London\& New Delhi: Bloomsbury, $2^{\text {nd }}$ ed. 2014.

Peters, John Durham. (2013). Exile, nomadism, and disapora: The stakes of mobility in the western canon, in Hamid Naficy (Ed.), Home, exile, homeland: Film, media, and the politics of place (pp.17-41). London \&New York: Routledge.

Pétriat, Philippe. (2017). "Diaspora or network? The hadhrami diaspora reconsidered through the lens of trade" in Noel Brehony (Ed.), Hadhramaut and its diaspora: Yemeni 
politics, identity and migration (pp.187-204). I.B. Tauris: London \&New York.

Reham, Diane.(2013) "Jhumpa Lahiri on writing, her family and the immigrant experience." The Diane Rehm Show. Retrieved from https://www. youtube. com/ watch? v= bd4yg4IjFKQ

Robbins, Sky Dylan. (2013). "Jhumpa Lahiri at work." New Yorker.com Retrieved from

https://www.newyorker.com/books/page-turner/videojhumpa-lahiri-at-work

Rutherford, J.(1990). "The third space: Interview with Homi Bhabha" Identity, community, culture difference (pp.207-221). London: Lawrence and Wishart.

Said, Edward.(2000). Reflections on exile\& other essays, Harvard University Press.

Schillinger, Liesl. (2008). "American children." Sunday Book Review. Retrieved from

https://www.nytimes.com/2008/04/06/books/review/Schillinge r3-t.html 